Representing Islam in the Eyes of the Self and the Other, Dewi Hermawati R. 113

\title{
REPRESENTING ISLAM IN THE EYES OF THE SELF AND THE OTHER: A CRITICAL DISCOURSE ANALYSIS OF NEWSPAPER ARTICLES
}

\author{
Dewi Hermawati Resminingayu
}

\begin{abstract}
Abstrak
Semenjak terorisme di Indonesia dikaitkan dengan kelompok Muslim ektstrimis, pemberitaan mengenai Islam di media tidak terlepas dari kedua aspek tersebut. Akibatnya, penelitian mengenai Islam di media hanya terpaku pada topik terorisme. Berdasarkan fakta tersebut, penelitian ini mengusung isu mengenai Muslim dan minoritas Cina di Indonesia, khususnya perayaan Imlek 2013 yang dikaitkan dengan isu agama Islam. Data yang digunakan dalam penelitian merupakan dua artikel koran. Artikel pertama ditulis oleh jurnalis Agence France Presse (AFP) yang mewakili media internasional sedangkan artikel lainnya dibuat oleh The Jakarta Post yang merupakan media nasional. Teori utama dalam penelitian ini adalah Analisis Wacana Kritis (AWK) yang digagas oleh Norman Fairclough. Teori ini terdiri atas dua level analisis yaitu communicative event analysis dan order of discourse analysis. Teori Orientalisme milik Edward W. Said mengenai the self dan the other diaplikasikan sebagai teori pendukung untuk menganalisis konteks sosial kedua artikel. Dalam hal ini, AFP mewakili the self sementara The Jakarta Post mewakili the other. Berdasarkan teori-teori yang telah diaplikasikan, dapat disimpulkan bahwa the self merepresentasikan Islam di Indonesia secara negatif sementara the other mereprentasikan Islam di Indonesia secara objektif.
\end{abstract}

\section{Kata Kunci}

analisis wacana kritis, Islam, Indonesia, media nasional dan luar negri, representasi.

\begin{abstract}
Since terrorism in Indonesia was associated to Moslem extremists, news regarding Islam has been mostly associated with those two aspects. In results, the concern of researches related to Islam in media only focuses on terrorism issue. Providing this background, this research is aimed to raise the issue related to Moslems and the Chinese minority in Indonesia, specifically in the celebration of Chinese New Year 2013 which is associated with Islamic issue. The data of this research are two newspaper articles. The first article is written by a journalist working for Agence France Presse (AFP) as the foreign media. Meanwhile, the other is written by The Jakarta Post which is the national media. The pivotal theory applied in this research is Critical Discourse Analysis (CDA) by Norman Fairclough. This theory comprises of two notions of analysis namely communicative event analysis and order of discourse analysis. Orientalism theory by Edward W. Said regarding the self and the other is also applied to analyze the socio-cultural context of the data. In this case, AFP represents the self, while The Jakarta Post is the other. After conducting thorough analysis, the findings disclose that the self represents Indonesian Islam negatively. In contrast, the other represents Indonesian Islam objectively
\end{abstract}

\section{Keywords}

critical discourse analysis, Indonesia, Islam, national and foreign media, representation. 


\section{BACKGROUND}

Bali Bombing I in 2002 marked the spread of news regarding Moslem extremists and terrorism in Indonesia not only in national media but also in foreign media. As a result, researches related to Islam $^{1}$ in media only focus on the issue of terrorism. To take an example, a research conducted by Akbardzadeh and Smith in 2004 brought the issue of Islam and terrorism in newspaper articles. Quantitative and qualitative methods were applied in that research. The results of the quantitative method showed that news regarding Indonesia was always related to terrorism, Bali Bombings, Jemaah Islamiyah, and Moslem extremists. Meanwhile, the results of the qualitative methods using Orientalism theory discerned that the West was regarded as the self who was portrayed as the good guy. On the other hand, Moslems were the other who was considered the bad guys. This reveals the fact that the image of Indonesian Islam has become negative due to its representation in the news.

In spite of this, other significant issues related to Islam are actually potential to be analyzed. The issue of the Moslems and the Chinese minority ${ }^{2}$ in Indonesia particularly regarding the celebration of Chinese New Year 2013 has been recently raised by national and foreign media. No research has been conducted to analyze this issue. Providing this background, this research aims to analyze the representation of Indonesian Islam in the news concerning Chinese New Year 2013.

Two newspaper articles are used as the data of this research. The first news is an article titled Indonesia Islam Leaders Stir Row over Chinese New Year. This article is written by a journalist working for Agence France Presse (AFP). The second article is MUI Mixes Chinese New Year with Religion written by an Indonesian journalist working for The Jakarta Post. Since the first news is written on behalf of foreign media and the latter on behalf of national media, these data offer two perspectives regarding the same issue. It becomes important to be analyzed, for news can affect or at least influence readers' perceptions (Richardson, 2007). To put it in Hartley's words (1982), news shapes readers' reality.

More importantly, both articles are published online. Since AFP is a news agency, the first article is published by various leading newspapers in many countries such as The Straits Times in Singapore, Bangkok Times in Thailand, Global Post in the USA, Ahram Online in Egypt, Borneo Insider in Malaysia, South China Morning Post in China, IOL News in South Africa, and MENAFN News in Middle East and North Africa. It is also possible for foreigners to read the news written by The Jakarta Post online. As a result, the two articles can shape the readers' reality around the world. The image of Indonesian Islam in the worldwide is likely affected by the presences of these two articles as well.

\footnotetext{
1 Islam in this research refers to Islam in Indonesia only.

2 The term Chinese minority is used to explain the Chinese descendants who have Indonesian nationality.
} 
The way news shapes reality cannot be separated from the fact that news is put into the category of discourse. One characteristic of discourse is to shape the world, and at the same time discourse is shaped by the world (Johnstone, 2002). In other words, the creation of discourse is influenced by what happens in the world and conversely. Thus, I will apply the theory of critical discourse analysis (CDA) within media discourse by Norman Fairclough to analyze the data. By applying CDA supported by the theory of discourse and ideology, the concept of representation, and Orientalism theory, this research is aimed to discern the representation of Indonesian Islam depicted in the two articles concerning Chinese New Year 2013.

There are three hypotheses that will be proved after conducting thorough analysis towards the articles. Firstly, it is assumed that regardless of terrorism issue, the articles represent Indonesian Islam positively. Secondly, the identity of Indonesian Islam is constructed positively in the two articles. Lastly, the self and the other represent Indonesian Islam differently.

\section{LITERATURE REVIEWS}

\section{REPRESENTATION}

The concept of representation applied in this research is taken from Stuart Hall's work. According to Hall (2001), the work of representation can be disclosed from the binary form of representation. Hall (2001) derives this concept from linguistics account particularly Saussure's idea of binary opposition that explains how meaning is created through differences. It can be illustrated using the words rich and poor in which rich can be determined rich because it is contrasted to poor. However, Derrida (cited in Hall, 2001) believes that binary opposition is not exactly neutral, for one dominates the other. In the case of rich and poor, the word rich has more positive meaning than poor since the rich is usually depicted as the dominant compared to the poor. Hall (2001) also looks upon linguistics' theories from Bakhtin that states meaning is derived from the dialogue of one with another; this meaning is created from the differences seen among the participants. In other words, one cannot create meaning by himself. Thus, the presence of the other is significant in the dialogue.

Hall further discusses representational strategy by employing naturalization. He believes that culture can be contested, yet nature cannot; thus, in order to be accepted, differences should be naturalized (Hall, 2001). To illustrate, there have been naturalization of the black and the white. The black are seen as the subordinate and more primitive than the latter. Those two characteristics of the black, Hall (2001) argues, have been accepted as natural characteristics of them. Because of that, the white often get more privileges than the black.

To support Hall's work, it is important to understand the concept of misrepresentations specifically marginalization. It refers to the way a dominant 
group misrepresents a particular group by presenting it negatively (Eriyanto, 2001). Euphemism, dysphemism, labeling, and stereotyping are employed to do marginalization (Eriyanto, 2001). Euphemism refers to the use of refined words to refine the bad actions done by the dominant group. In contrast, dysphemism employs rude words to represent the sub-ordinate group. Meanwhile, labeling deals with the offended words that are used by the dominant group to represent other groups so that the dominant gains legitimate way to punish others (Eriyanto, 2001). Last, stereotyping is to set a particular group in a typical condition.

\section{DISCOURSE AND IDEOLOGY}

According to Johnstone (2002: 2), discourse is defined as "actual instances of communication in the medium of language". She further states that discourse is both the source and the result of communication (Johnstone, 2002). To put it simply, discourse is language in use. Foucault (cited in Johnstone, 2002: 45) expands the meaning as he claims that "discourse is one of the principal activities through which ideology is circulated and reproduced". It means that ideology works behind discourse.

According to Raymond William (1995: 26), ideology stands for "the formal and conscious beliefs of a class or other social group - as in the common usage of 'ideological' to indicate general principles or theoretical positions or, as so often unfavorably, dogmas." Such type of class or group is often the dominant one that imposes their beliefs towards other groups. Clark and Ivanic (1997) add the point that ideology of a group is usually believed as the real truth, for it is constructed to be common sense. As a result, the oppressive social system seems to be natural and desirable (Johnstone, 2002).

The theory of ideology is always related to the theory of hegemony proposed by Gramsci. According to Gramsci (cited in Clark and Ivanic, 1997), hegemony refers to a leadership of a class over other classes which is gained by getting the active consent of other classes to issue policies and make decisions. Here, ideology works within hegemony to gain the active consent without using coercive actions. Usually, the dominant class circulates its ideology behind continuous news or advertisements so that other classes accept it as common sense. By this means, the hegemony of the dominant is maintained.

\section{CRITICAL DISCOURSE ANALYSIS}

Critical Discourse Analysis (CDA) has to be distinguished from a mere Discourse Analysis (DA). DA aims to either analyze the subjectivity of discourse's creator or the objective reality of the discourse (Eriyanto, 2001). Meanwhile, CDA analyzes both aspects as well as criticizes it. To put in Bordieu's words (cited in Fairclough, 1995b: 56), CDA aims to reveal the causes and effects that connect "social practices in general and language in use in particular". CDA theory within media discourse proposed by 
Norman Fairclough is mainly applied in this research. This theory includes two notions of analysis namely Analysis of Communicative Events and Order of Discourse Analysis.

\section{ANALYSIS OF COMMUNICATIVE EVENTS}

Below is the diagram that marks the basic concept of the first notion of CDA.

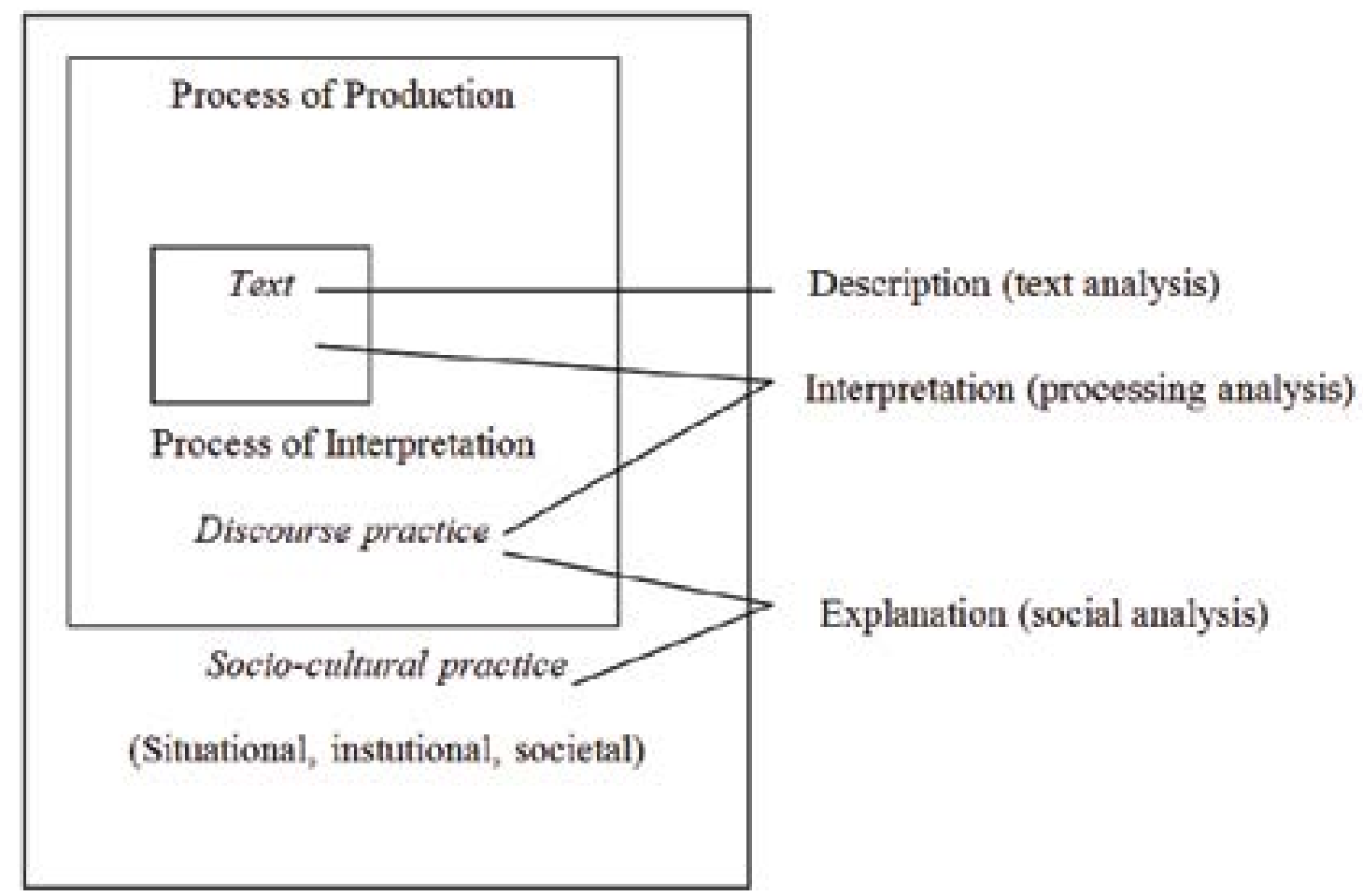

Diagram 1. Dimensions of Discourse ${ }^{3}$

This shows three-dimensional conception of discourse which affects threedimensional method of CDA. Therefore, the first notion includes three steps (Fairclough 1995b: 97):

1. Linguistic description of language text, either spoken or written: textual analysis.

2. Interpretation of the relationship between the (productive and interpretative) discursive processes and the text: discourse practice analysis.

3. Explanation of the relationship between the discursive processes and the social processes: socio-cultural analysis.

The first step is textual analysis that aims to discern the linguistic structure of the text. This analysis itself comprises of four sub-analyses. Firstly is the analysis of presupposition. Since news has limited space compares to other genres such as short story, the writer needs to employ presupposition in which he/she assumes that some 
information can be omitted because it can be found in other texts by the readers (Fairclough, 1995a). There are some ways to presuppose: using stative/implicative verbs, employing definite and possessive articles, and inserting wh-questions (Reah cited in Richardson, 2007). Attaching an adjective/noun to qualify noun phrase can also be used to presuppose meaning (Richardson, 2007). Giving a name to a particular group can presuppose meaning as well (Fairclough: 1995a).

Secondly is the analysis of representation in clause. The representation in clause can be analyzed at two levels. The first is at the vocabulary level by analyzing the use of metaphor and hyperbole (Richardson, 2007). Analyzing the metonym is another way to discern the representation at the level of vocabulary (Reisigl and Wodak cited in Richardson, 2007). The second is grammar level. Faircough (1995a) argues that this level can be analyzed by looking at the types of clauses: Action Type (SVO), Event Type (SV), State Type (SVC), Mental Process Type (senser), and Verbal Process Type (verbiage). Fairclough (1995a) also notices that nominalization can be analyzed in this level. In addition, Richardson (2007) puts his concern on truth modality expressed by using absolute category of verbs such as is and will, employing various way of hedging such as if-clause, and reducing uncertainty such as the use of could, might, would, and etc.

Thirdly is the analysis of representation in sequencing and combination clauses. Fairclough sees the importance of local coherence relation and global text structuring in this step. The first is analyzed by referring to three types of local coherence relations proposed by Halliday: elaboration, extension, and enhancement (Fairclough, 1995a). Four basic types of cohesion which are conjunction, lexical cohesion, reference, and ellipsis are also important in this analysis (Halliday and Hasan cited in Fairclough, 1995a). The latter can be analyzed by discerning the structure of news involving headline, lead, satellites, and sometimes wrap-up. Those analyses deal with the strategy of informational structuring by positioning and giving weight to the important information.

The last is picture analysis based on semiotics theory. This cannot be separated from the concept of sign, signified, and signifier. Specifically, it takes the account of Barthes' Language and Myth. Sign contains not only denotative meaning which can be disclosed using its language but also connotative meaning (myth) which is analyzed using its metalanguage (Barthes cited in Hall, 2003). Below is the diagram of Language and Myth.

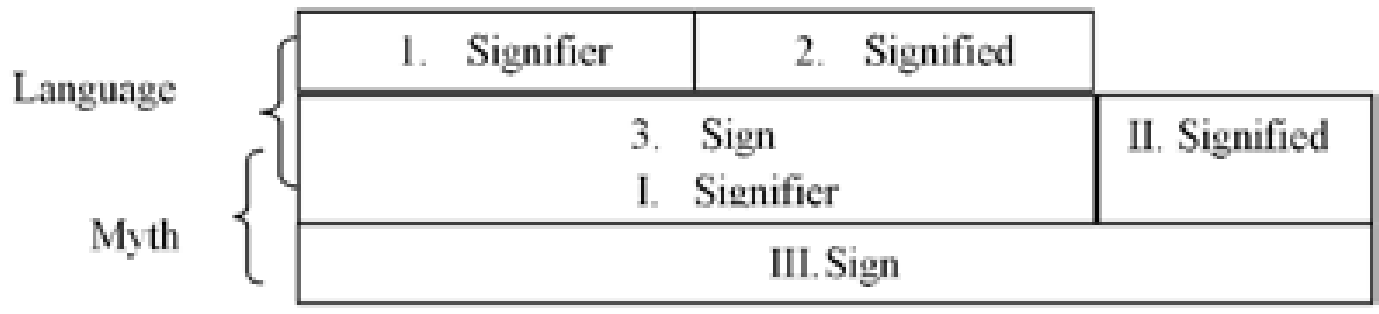

Diagram 2. Picture and $\mathrm{Myth}^{4}$

4 Taken from a book Mythologies by Roland Barthes page 113 
The second step of Communicative Event Analysis is discourse practice analysis which is based on two models of intertextuality. Firstly is Manifest Intertextuality which focuses on how other texts emerge in a text explicitly through some techniques namely representation, presupposition, negation, and metadiscourse (Fairclough cited in Eriyanto, 2001). Representation deals with journalist's choices to pick certain persons represented in the news. Presupposition, in this case, has the same point as the one explained in textual analysis. Negation is the negative version of presupposition. The last, metadiscourse is the way the journalist favors certain represented discourses.

Related to this, it is necessary to explain further regarding representing discourse (journalist's voice known as primary discourse) and represented discourse (others' voices quoted in the discourse known as secondary discourse). Ideally, journalist has to keep the boundary maintenance between primary and secondary discourses in order to differentiate them. Therefore, Fairclough (1995b) states three modes of representation: Direct Discourse (secondary discourse quoted directly), Indirect Discourse (secondary discourse presented using indirect speech), and UNSIGnaled (ID without reporting clause). Another concern is the equity and balance of the secondary discourses. Fairclough (1995b) argues that inequity and imbalance would be achieved by dividing voices into protagonist and antagonist.

Secondly is Interdiscursivity which refers to "mixing of diverse genres, discourses, or styles associated with institutional and social meanings in a single text" (Jian-guo, 2012: 1). It is related to four elements of interdiscursivity namely genre, activity type, style, and discourses (Fairclough cited Eriyanto, 2001). To illustrate, if the genre is news, the activity type could be hard news or soft news. Meanwhile, style is the manner of interaction among the participants as well as the choice of words and terms used in the interaction (Eriyanto, 2001). Discourse in this case refers to the themes of the news.

The last step of Communicative Event Analysis is socio-cultural analysis. In this analysis, the data are put in the wider context - the socio-cultural context. The theory of Orientalism by Edward W. Said is applied in this step. Later, this theory will be explained further.

\section{ORDER OF DISCOURSE ANALYSIS}

The order of discourse analysis deals with the order of discourses present in the news. This second notion comprises of two analyses namely choice relation and chain relation. Choice relation deals with the choices that are made during the production of discourse. The analysis of chain relation is based on the idea that a communicative event can be regarded as a chain of communicative events (Fairclough, 1995a). The changes of discourses while moving along the chain become the main focus of the analysis (Fairclough, 1995a). 


\section{ORIENTALISM}

According to Edward W. Said, there are two important aspects of Orientalism. The first is the geographical distinction which is determined by the line that divides two continents: Europe (the self) and Asia (the other) (Said, 1979). Second, the contrasting characteristics in which the values of the other are always against the normal values of the self (Said, 1979). Said (2002) further explained that from the perspective of the self, Islam belongs to the orient or the other. Although the comparison between Islam as a religion and the West as a region seems incompatible, Said (2002) argued that many countries with Islamic backgrounds are characterized and regarded as one entity. It is because Islam with its various societies, histories, and languages is considered backward and primitive (Said, 2002).

All various aspects of Moslem's world are reduced because of the significant hatred of the West towards Islam (Said, 2002). These reductions result in generalization towards anything related to Islam. The opinion about Islam nowadays, for instance, cannot be separated from terrorism (Said, 2002). Another concern towards Islam is its backwardness. For the West, it is a fate that Islam is subordinate to the West; therefore, modernization of Islam is necessary done by the West (Said, 2002).

Moreover, the geopolitical background of Islam pictures that Islam confronts the West through its deviant values that challenge normal values in the West (Said, 2002). This has always been the case that the West cannot accept. Therefore, Islam which is represented by the Moslems are always labeled the fundamentalist (Said, 2002). This label remains unchanged, so Islam is always associated with bad images.

\section{METHODS OF ANALYSIS}

The methods of analysis in this research are comprised of three steps. The first step is collecting the data from the newspapers' websites. Next, the data are analyzed using three levels of analysis in the theory of Critical Discourse Analysis within media discourse. The last step is to prove the hypotheses based on the findings of the analysis.

\section{FINDINGS}

Before the findings are explained in detail, I will summarize the contents of the two articles. The first article tells the refusal of Indonesians Moslems particularly the representative of $\mathrm{MUI}^{5}$ and FPI (Front Pembela Islam) to allow Moslems joining the

\footnotetext{
5 MUI is a national council of Moslem clerics that has the support from government although it is a nongovernmental organization (Ichwan, 2005: 48). The political role of MUI in Indonesia is to issue fatwas and non legal recommendations (tausiyahs) which are the tools to bring Moslem Indonesians towards its orthodoxy (Ichwan, 2005: 46).
} 
celebration of Chinese New Year 2013 locally known as Imlek ${ }^{6}$. They argue that the celebration is a religious celebration. In contrast, the head of the Chinese-Indonesian Youth Association disagrees with them, for he believes that the celebration is cultural. Beside this debate, the article describes the suffering of the Chinese in Soeharto's era (New Order regime), the celebration of Imlek akin with Islamic procession in Solo, and two female Moslem visiting a Buddhist temple. The second article reports the contesting opinions of two Muslim figures. The first figure is MUI Representative (the same person as in the first article) who prohibits Moslems joining Imlek celebration. The second figure is Mohammad Dian $\mathrm{Nafi}^{7}$ as the head of al-Muayyad Islamic Boarding School who allows Moslem to do so.

The findings are divided into two sections based on the notions of CDA.

\section{Findings of Communicative Event Analysis}

There are three parts of findings for the first notion.

\section{Textual Analysis}

Presupposition: First Article

\begin{tabular}{|l|l|}
\hline The Methods Used & The Discourse \\
\hline $\begin{array}{l}\text { Naming by attaching } \\
\text { adjective/noun to } \\
\text { qualify nouns. }\end{array}$ & $\begin{array}{l}\text { 2. } \\
\text { the country's top Muslim clerical body (line 8) } \\
\end{array}$ \\
$\begin{array}{l}\text { 3. } \\
\text { the Chinese-Indonesian Youth Association (line 21) } \\
\text { politician (line 39) }\end{array}$ \\
\hline
\end{tabular}

From the table above, there are several subjects that are presupposed. First, the adjective top presupposes the Muslim clerical body mentioned here is the highest body in the country. In the discourse, this refers to Indonesia Ulema Council (MUI). Second, the phrase hard-line presupposes that the FPI is an extremist group, for FPI can actually be translated into English without that phrase. Third, it presupposes a youth Chinese organization locally known as ASPERTINA (Asosiasi Peranakan Tionghoa Indonesia). The addition of the noun youth presupposes that it is comprised of the young Chinese

\footnotetext{
6 According to Hoon (2009: 7), "Imlek is a traditional celebration of the Chinese, yet it was co-opted as a religious festival because Confucians claimed it was a sacred day that commemorated the birth of Confucius, just like Christmas celebrated the birth of Jesus Christ."

7 Dian Nafi is a member of Nadhlatul Ulama which is nationally known as a mainstream moderate Islamic organization in Indonesia. He is quite famous for his participations in conflict resolutions between ethnics such as in Central Borneo and Celebes in Indonesia. His actions are also internationally acknowledged, for he has been invited to take part in peace and conflict resolution forums and trainings in USA and Africa.
} 
although the original name does not state so. Last, it is presupposed that Abdurrahman Wahid ${ }^{8}$ has strong faith in Islam, leadership quality, and political knowledge.

Presupposition: Second Article

\begin{tabular}{|l|l|}
\hline The Methods Used & The Discourse \\
\hline Using stative verbs. & $\begin{array}{l}\text { The celebration contains portions of Buddhism spiritual } \\
\text { teachings (line 8) } \\
\text { The celebration is part of the Chinese people's way of welcoming } \\
\text { spring (line 14) }\end{array}$ \\
\hline
\end{tabular}

From the table above, there are two contesting opinions regarding Chinese New Year celebration. The first is the opinion of MUI representative which presupposes that the celebration is a religious celebration. Meanwhile, the second is the opinion of the head of Al-Muayyad Islamic boarding school that presupposes it is a cultural celebration.

Representation in Clause: First Article

\begin{tabular}{|l|l|}
\hline The Methods Used & The Discourse \\
\hline Vocabulary choice & $\begin{array}{l}\text { 1. illogical and a sign of outdated thinking in some Islamic } \\
\text { organizations (line 19) }\end{array}$ \\
\hline Using passive sentence & 2. many Chinese - were killed and others tortured. (line 38) \\
\hline Using stative verbs & $\begin{array}{l}\text { 3. if it's part of a religious ritual,(line 13) } \\
\text { 4. Chinese New Year is not a religious celebration (line 20) }\end{array}$ \\
\hline
\end{tabular}

In the first point, the choice to present Moslem using negative words has stated the characteristics of Moslems in the discourse. It is categorized as hyperbole, for those words can be syntagmatically replaced by inappropriate. The second point emphasizes the object that is affected by the action; therefore, its focus is the suffering of the Chinese. The third point employs hedge by using if-clause while the fourth does not. It can be inferred that the fourth which is the opinion of the Chinese leader has higher degree of truth than the previous which is the opinion of Islamic leader.

\footnotetext{
8 Abdurrahman Wahid was once the head of Nadhlatul Ulama which is one of the two biggest moderate Moslem organizations in Indonesia.
} 
Representation in Clause: Second Article

\begin{tabular}{|l|l|}
\hline The Methods Used & The Discourse \\
\hline Using Action Type & $\begin{array}{l}\text { 1. } \\
\text { Surakarta's Indonesia Ulema Council (MUI) chief Zainal Arifin } \\
\text { Adnan has prohibited Muslims (line 3-4) }\end{array}$ \\
\hline $\begin{array}{l}\text { Using Mental Pro- } \\
\text { cess Type }\end{array}$ & $\begin{array}{l}\text { 2. } \\
\text { Mohammad Dian Nafi of the al-Muayyad Islamic boarding } \\
\text { school in Kartasura sees nothing wrong (line 11) }\end{array}$ \\
\hline
\end{tabular}

In the first point, the choice to use action type allows the subject to affect the object. Meanwhile, the second employs mental process type in which the senser only delivers his opinion. From this analysis, it can be discerned that MUI has more authority than Dian Nafi.

Representation in Sequencing and Combining Clause: First Article

\begin{tabular}{|l|ll|}
\hline The Methods Used & The Discourse \\
\hline $\begin{array}{l}\text { Using forward re- } \\
\text { ference }\end{array}$ & $\begin{array}{l}\text { some Islamic leaders have ignited a religious row (line 1) } \\
\text { 2. }\end{array}$ & But ethnic Chinese leaders say such comments (line 18) \\
\hline $\begin{array}{l}\text { Using extension for } \\
\text { complex sentence }\end{array}$ & $\begin{array}{l}\text { 3. } \\
\text { Despite the cleric's comments, a Javanese-style Lunar New Year } \\
\text { celebration was held (line 26-27) }\end{array}$ \\
\hline
\end{tabular}

The use of plural nouns in the first and second points shows that the first article assumes many people are involved in the debate regarding Chinese New Year celebration. From the position of clauses in the third point, it is obvious that the subclause is more important than the main clause. Thus, it emphasizes the insignificance of the Moslem clerics' comments. Moreover, from global text structure, the position of the third point marks the rebuttal towards the Moslem clerics' comment, for it is placed in the middle of the article after the refusal of the Moslems.

Representation in Sequencing and Combining Clause: Second Article

\begin{tabular}{|l|ll|}
\hline The Methods Used & The Discourse \\
\hline Using reference & 1. & Two local Muslim figures in Surakarta (line 1) \\
\hline $\begin{array}{l}\text { Using extension for } \\
\text { complex sentence }\end{array}$ & $\begin{array}{l}\text { 2. } \\
\text { In contrast, Mohammad Dian Nafi of the al-Muayyad Islamic } \\
\text { boarding school in Kartasura sees nothing wrong (line 11) }\end{array}$ \\
\hline
\end{tabular}

Different from the first article, the second article states the exact number of people engaged in the debate. The first point clearly states the number is two - that will be referred in the discourse later. The use of conjunction in the second point shows the 
sequence of the discourse in which the later contrasts the previous. It shows contesting opinions between Dian Nafi and MUI representative.

Picture Analysis: First Article

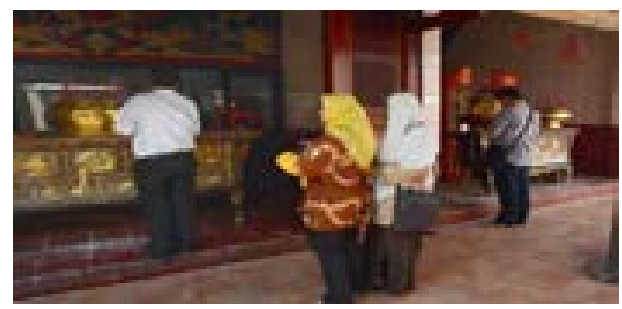

Picture 1. Two Muslim women visit a Buddhist temple in Jakarta (AFP). ${ }^{9}$

The picture above is analyzed using the diagram of Language and Myth proposed by Barthes below. The importance of this diagram is the myth hidden. The language shows the denotative meaning which two female Moslems visit a Buddhist temple. The myth, in contrast, reveals that actually Moslems are not expected to go to a prayer place of other religion. Thus, this picture invalidates the headline and the clerics' comment, for those Moslems consume the celebration by visiting the temple.

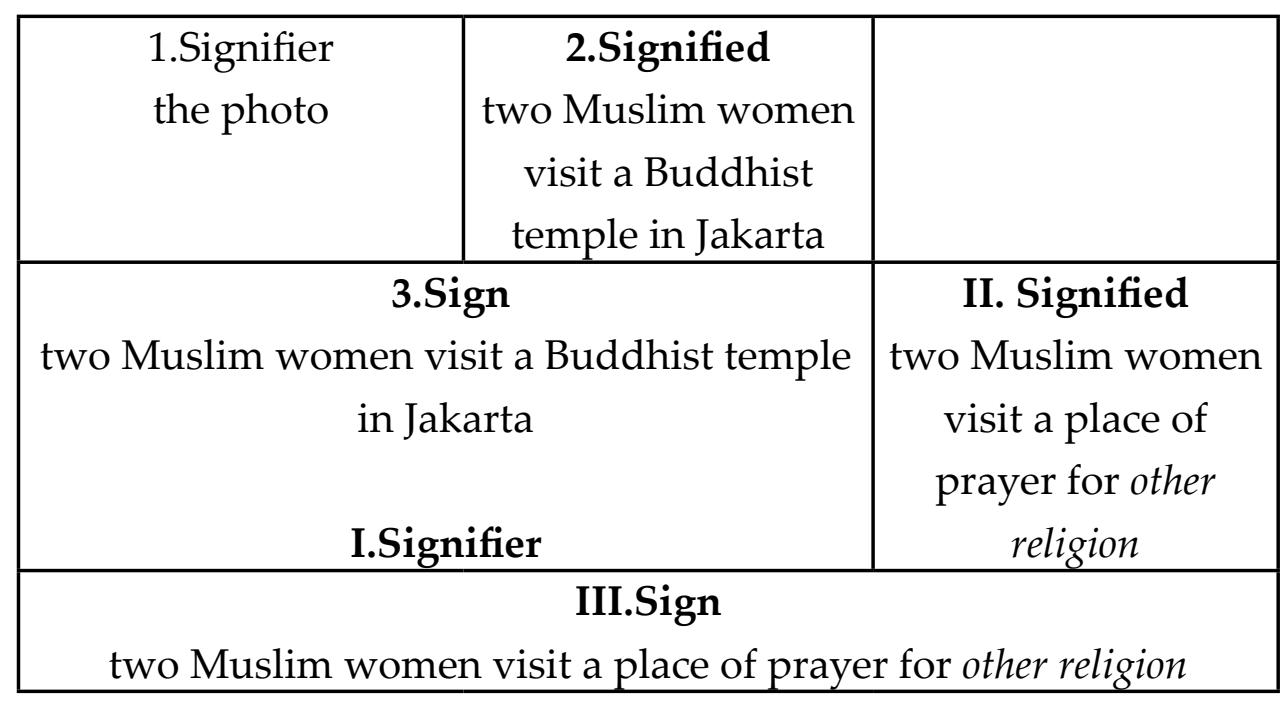

\section{DISCOURSE PRACTICE ANALYSIS}

Manifest Intertextuality: First Article

There are four aspects that need to be analyzed in this level: representation discourse, presupposition, negation, and metadiscourse. Since the second and third have been analyzed in the textual analysis, they will no longer be discussed. The first aspect

\footnotetext{
9 Taken from http://www.scmp.com/news/asia/article/1147326/indonesia-islam-leaders-stir-row-overbuddhist-chinese-new-year on March 6th, 2013.
} 
deals with other discourses that are represented in the discourse (the news). Regarding this, the instances ${ }^{10}$ in the discourse have been categorized as follows.

$\begin{array}{ll}\text { Primary discourse } & : 10 \text { instances } \\ \text { Secondary discourse (direct discourse) } & : 6 \text { instances } \\ \text { Secondary discourse (indirect discourse) } & : 4 \text { instances } \\ \text { Mixed of primary and secondary discourses } & : 2 \text { instances }\end{array}$

The first article relies more on primary discourse, for the primary discourses take 10 instances added by 2 ambiguous instances (mixed discourses) compared to 10 instances of secondary discourses. Also, the use of ID and mixed discourses weakens the boundary maintenance of the discourse. Related to the fourth aspect, the journalist favors the voice of Chinese leader more than the Islamic leaders. It can be discerned through the findings of textual analysis in which the Moslems depicted negatively.

Manifest Intertextuality: Second Article

Below are the instances in the second article.

$\begin{array}{ll}\text { Primary discourse } & : 3 \text { instances } \\ \text { Secondary discourse (direct discourse) } & : 2 \text { instances } \\ \text { Secondary discourse (indirect discourse) } & : 2 \text { instances } \\ \text { Mixed of primary and secondary discourses } & : 0 \text { instance }\end{array}$

Different from the first article, the second article relies more on the secondary discourse. The boundary maintenance is also low since only 2 instances using DD. Nevertheless, the journalist does not favor any represented discourse (secondary discourse), for she does not use inflammatory language to take side.

\section{Interdiscursivity}

Ideally, news should be delivered informatively. Nevertheless, other tones are found in the first article beside informative tone. For instance:

And if it's part of a religious ritual, we must not celebrate it (line 13)

The sentence above has the quality of being persuasive. Therefore, the interdiscursivity in the first article can be disclosed by looking at the style of the writing. Similar to the first article, the second one also employs persuasive tone as in:

\footnotetext{
${ }^{10}$ Instances are the number of sentences in the discourse. See appendix 3 for further description.
} 
The best attitude for a Muslim toward this event is to ignore it (line 9-10)

Thus, style also used to bear the interdiscursivity in the second article.

\section{SOCIO CULTURAL ANALYSIS}

In the first article, AFP as the producer is regarded as the self that represents the West while Islam belongs to the other. From the analyses above, specific choice of words are employed to delineate Moslems such as illogical and outdated thinking. This supports the stereotype of Islam in Orientalism which is backward. Moreover, the represented discourses are the extremists/fundamentalists (MUI and FPI) although moderate Moslems are the majority in Indonesia. This reveals the strategy of the self to spread the stereotype of Moslems, let alone the hatred feelings towards them.

In contrast, the Jakarta Post as the producer of the second article is regarded as the other. The Moslems presented in the second article are the fundamentalist (MUI representative) and the moderate (Dian Nafi as the member of NU- moderate Islamic organization). These represented discourse counterattack the stereotype of Moslems in Orientalism. Therefore, the ideology of the other contests that of the self.

\section{ORDER OF DISCOURSE ANALYSIS}

Choice relation: First Article

The choice to order the discourses in the first article is illustrated as follow: Soeharto - Moslem extremists - the Chinese - Soeharto - Abdurrahman Wahid - female Moslem. The presence of Soeharto pictures the suffering of the Chinese in the past. The Moslem extremists are presented to refuse the involvement of Moslem in the celebration. The Chinese, in contrast, disagrees with the Moslem extremists. Abdurrahman Wahid does not take part in the debate, for his presence only shows the end of Soeharto's regime. Last, the female Moslems are depicted visiting a Buddhist temple which is actually against the clerics' comments. It can be inferred that this choice relation does not really support the Moslem extremists since the suffering of the Chinese leads the readers to take side to them and other discourses are against the Moslem extremists.

\section{Choice relation: Second Article}

The order of the second article only involves: MUI representative - Dian Nafi. MUI representative prohibits Moslems to join Chinese New Year celebration. Meanwhile, Dian Nafi allows them. From this choice, the article does not take side, for neither MUI representative and Dian Nafi are supported. 


\section{Chain relation}

The chain relation in the first and second article is the same. Both quote the comments from outside the media and transform them into news as represented discourses. This enables changes from intellectual tone into colloquial tone in order to fit the characteristics of the news. Also, these changes allow broader readers to understand the news, for the intellectual tone might be difficult for some people.

\section{DISCUSSION}

The findings yield three important matters related to the hypotheses. Firstly, both the self and the other do not represent Islam positively. In the first article, the use of negative words, the grammatical structure weakening the Moslem fundamentalists' opinions, and the picture invalidating the headline are some factors that undermine Islam. It is considered as marginalization of Moslems, for the use of negative words is a dysphemism method. Also, positioning fundamentalist Moslems below the Chinese linguistically is the way to label the Moslems. Therefore, the first article employs misrepresentation, in this case marginalization. Meanwhile, even though the second article employs non-inflammatory language, it does not depict Islam positively either. It is more likely to be an objective delineation.

Secondly, the identity of Moslems in the first article is constructed to be fundamentalist Moslems. Although both fundamentalist and moderate Moslems are present in the first article, it goes with binary form of representation concept. The fundamentalist and moderate Moslems are binary, yet the fundamentalist dominates the other. It can be discerned from the choice of represented discourses which all are fundamentalists while Abdurrahman Wahid as the moderate Moslem is not given voice in the article. In contrast, the represented discourses given voices in the second article are not only fundamentalist but also moderate. Therefore, the identity of Moslems in the second article is various.

Thirdly, the self and the other represent Islam differently. The self represent Islam based on the theory of Orientalism. This is revealed by the characteristics of Moslems in the first article: backward and fundamentalist. On the other hand, the other counterattacks the Orientalism by opposing the stereotype of Islam. The other presents both the moderate and the fundamentalist without any specific characteristics.

\section{CONCLUSION}

To conclude, both the self and the other bear their ideologies in representing Islam. Those different ideologies lead to different results in creating news regarding Islam. Nevertheless, the ideology of the self is more likely to be accepted, for the news created by AFP is published in more newspapers' websites than the news of The Jakarta Post. The 
news of AFP has high possibility to lead more people to accept its ideology. The ideology naturally constructs people's perception that Indonesian Moslems are backward and fundamentalist. As a result, this perception is not contested. It reveals the fact that the news of AFP legitimate the hegemony of the self - the West.

\section{BIBLIOGRAPHY}

Akbarzadeh, Shahram \& Smith, Bianca. (2005). The Representation of Islam and Muslim in the Media. Australia: Monash University.

Ayuningtyas, Kusumasari. (2013). MUI Mixes Chinese New Year with Religion. Retrieved February 18 ${ }^{\text {th }}, 2013$ from http://www.thejakartapost.com/news/2013/02/05/ mui-mixes-chinese-new-year-with-religion.html

Barthes, R. (1972). Mythologies (Annette Laver, Trans). New York: The Noonday Press.

Clark, Romy and Ivanic, Roz. (1997). The Politics of Writing. New York: Routledge.

Eriyanto. (2001). Analisis Wacana: Pengantar Analisis Teks Media. Yogyakarta: LKiS Yogyakarta.

Fairclough, Norman. (1995a). Media Discourse. London: Longman Publishing

Fairclough, Norman. (1995b). Critical Discourse Analysis: The Critical Study of Language. New York: Longman Publishing.

Hall, Stuart. (2001). The Spectacle of The Other. In Margaret Wetherell, Stephanie Taylor, and Simeon J. Yates (Eds), Discourse Theory and Practice: A Reader (pp.324-344 ). London: Sage Publication.

Hall, Stuart. (2003). The Work of Representation. In Stuart Hall (Ed.), Representation: Cultural Representations and Signifying Practices (pp. 13-74).Great Britain: Sage Publication.

Hartley, John. (1982). Understanding News. England: Routledge.

Hoon, Chang-Yau. (2009). More than a Cultural Celebration: The Politics of Chinese New Year in Post-Suharto Indonesia. Chinese Southern Diaspora Studies, 3, 90-105. Retrieved from http://works.bepress.com/changyau_hoon/1/

Ichwan, M. N. (2005). Ulama, State and Politics: Majelis Ulama Indonesia After Suharto. Islamic L. \& Soc'y, 12, 45.

Jian-guo, W. U. (2012). Studies on Interdiscursivity. Sino-US English Teaching, 9(7), 1312-1317.

Johnstone, Barbara. (2002). Discourse Analysis. Oxford: Blackwell Publishers.

Poniah, Kevin. (2013). Indonesia Islam Leaders Stir Row over Chinese New Year. Retrieved February 18 ${ }^{\text {th }}, 2013$ from http://kevinponniah.com/2013/03/01/islam-leaders-stir-rowover-chinese-new-year/.

Richardson, John E. (2007). Analyzing Newspaper. New York: Palgrave Macmillan.

Said, Edward W. (2002). Covering Islam: Bagaimana Media dan Pakar Menentukan Cara Pandang Kita terhadap Dunia (Apri Danarto Trans). Yogyakarta: Penerbit Jendela.

Said, Edward W. (1979). Orientalism. US: Random House Inc. 
Two Muslim Woman Visiting A Buddhist Temple [Image 1]. (2013). Retrieved March $6^{\text {th }}, 2013$ from http://www.scmp.com/news/asia/article/1147326/indonesia-islam-leadersstir-row-over-buddhist-chinese-new-year

William, Raymond. (1995). The Sociology of Culture. Chicago: The University of Chicago Press.

\section{APPENDIX 1. FIRST ARTICLE}

\section{INDONESIA ISLAM LEADERS STIR ROW OVER CHINESE NEW YEAR}

By Kevin Ponniah (AFP) - Feb 9, 2013

JAKARTA - As Indonesia and other countries with Chinese diasporas welcome the Year of the Snake, some Islamic leaders have ignited a religious row by declaring the celebrations "haram" and off limits for Muslims.

After decades of repression under the dictatorship of Suharto, who rose to power after a bloody purge of communists and Chinese in the late 1960s, Chinese-Indonesians are now accepted in mainstream society of the largely Muslim nation.

Lunar New Year is also now a public holiday in Indonesia, where it is known as “Imlek".

But a local leader of the country's top Muslim clerical body has declared the celebration "haram" (forbidden), saying its rituals are tied up with Buddhist practices, particularly those that take place in temples.

"We cannot separate religion from culture, so we're being cautious," Zainal Arifin, head of the Indonesian Ulema Council in the city of Solo, told AFP.

"And if it's part of a religious ritual, we must not celebrate it. It's the same case with Christmas and other religious celebrations."

The hardline Islamic Defenders Front (FPI) said clerics would spread the message to Muslims through mosque loudspeakers, and warn Chinese-Indonesians not to invite Muslims to celebrations.

But ethnic Chinese leaders say such comments about a traditional festival are illogical and a sign of outdated thinking in some Islamic organisations.

"Chinese New Year is not a religious celebration and it's especially not a Buddhist celebration," said Andrew Susanto, president of the Chinese-Indonesian Youth Association.

He said marking the Lunar New Year was no different to celebrating the new year in other cultures.

"I don't think that's what most Indonesians think," he said, adding the festivities have over time become an Indonesian tradition.

Despite the cleric's comments, a Javanese-style Lunar New Year celebration was 
held in Solo last week, with thousands joining a procession akin to those commemorating Islamic holidays.

Local monks released 888 songbirds and catfish -- eight being a lucky Chinese number -- and distributed cakes to the jovial crowd.

Chinese-Indonesians make up around nine million of the nation's 240 million people, most practising Christianity, Buddhism or Confucianism.

Suharto, who ruled Indonesia with an iron fist for more than three decades until 1998, banned Chinese languages and symbols, and forced Chinese-Indonesians to change their names.

His rule began after an anti-Communist purge in 1965-1966, in which at least 500,000 people considered communists or sympathisers -- many Chinese -- were killed and others tortured. Rights activists say two million perished.

Abdurrahman Wahid, an Islamic religious leader and politician who became the first elected president after Suharto stepped down, lifted the ban on Chinese culture in 2000, allowing ethnic Chinese to once again openly celebrate Lunar New Year.

In Glodok -- Jakarta's Chinatown which was reduced to rubble in the 1998 riots at the end of Suharto's rule -- two Muslim women wearing headscarves soaked up the atmosphere, as vendors sold traditional red money envelopes and cobra oil to mark the Year of the Snake.

"I'm Muslim, so I don't myself take part in celebrations," said one of the women, Widi Astudi, 37, as she visited a Buddhist temple Friday.

"But Indonesia is a tolerant country, and the Chinese here are Indonesians, so there's no harm in visiting the temples and appreciating how they celebrate."

Copyright ( 2014 AFP. All rights reserved.

\section{APPENDIX 2. SECOND ARTICLE}

\section{MUI MIXES UP CHINESE NEW YEAR WITH RELIGION}

Kusumasari Ayuningtyas, The Jakarta Post, Surakarta | Archipelago | Tue, February 05 2013, 7:15 PM

Two local Muslim figures in Surakarta hold different views on how Muslims should react to Chinese New Year, locally known as Imlek, which falls on Sunday.

Surakarta's Indonesia Ulema Council (MUI) chief Zainal Arifin Adnan has prohibited Muslims from participating in any Chinese New Year festivities at any level, let alone attend any prayers for the celebration.

He said that even if a Muslim was of Chinese descent, still he or she should keep a distance from such celebrations. 
"The celebration contains portions of Buddhism spiritual teachings and it is therefore prohibited for any Muslims to participate. The best attitude for a Muslim toward this event is to ignore it," Zainal said on Tuesday.

In contrast, Mohammad Dian Nafi of the al-Muayyad Islamic boarding school in Kartasura sees nothing wrong with Muslims attending celebrations because Chinese New Year was more of a cultural event than a religious one.

“The celebration is part of the Chinese people's way of welcoming spring, which is usually perceived as the best time of the year. Thus it has nothing to do with religion and of course Muslims can join in the festivities, strengthening social relations with our ethnic Chinese brothers and sisters," he said. 